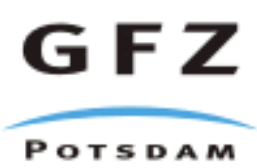

Originally published as:

Hirsch, K. K., Scheck-Wenderoth, M., Paton, D. A., Bauer, K. (2007): Crustal structure beneath the Orange Basin, South Africa. - South African Journal of Geology, 110, 2-3, 249260

DOI: 10.2113/gssajg.110.2-3.249. 


\section{Crustal structure beneath the Orange Basin, South Africa}

Katja K. Hirsch', Magdalena Scheck-Wenderoth², Douglas A. Paton³, Klaus Bauer ${ }^{4}$

${ }^{1}$ GeoForschungsZentrum Potsdam, Telegrafenberg,14473 Potsdam, Germany: hirsch@gfz-potsdam.de 2GeoForschungsZentrum Potsdam, Telegrafenberg,14473 Potsdam, Germany: leni@gfz-potsdam.de ${ }^{3}$ School of Earth and Environment, University of Leeds. UK: douglas.paton@gmail.com

4GeoForschungsZentrum Potsdam, Telegrafenberg,14473 Potsdam, Germany: klaus@gfz-potsdam.de 


\begin{abstract}
Although the development of passive margins has been extensively studied over a number of decades, significant questions remain on how mantle and crustal dynamics interact to generate the observed margin geometries. Here, we investigate the Orange Basin, located on the south-west African continental margin. The basin fill is considered to comprise a classic rift-drift passive margin sequence recording the break-up of Gondwana and subsequent opening of the South Atlantic Ocean. Based on interpreted seismic reflection data, a 3D geological model was first constructed. Subsequently, an isostatic calculation (Airy's model) using a homogeneous middle and lower crust was applied to this geological model to determine the position of the Moho for an isostatically balanced system. Isostatic sensitivity tests were applied to the model, and their gravity response were validated against different crustal structures for the basin. The best-fit model requires dense, presumably mafic material, in the middle and lower crust beneath the basin and an abrupt change to less dense material near the coast to reproduce the observed gravity field.
\end{abstract}

\title{
Introduction
}

The Orange Basin offshore southwest Africa (Fig. 1) is located within the passive continental margin of the South Atlantic between $31^{\circ}$ and $33.5^{\circ} \mathrm{S}$. It developed within a divergent plate boundary setting in response to lithospheric extension related to the break-up of South America and Africa in the Late Jurassic, followed by seafloor spreading and the opening of the South Atlantic Ocean in the Early Cretaceous around 136 Ma (Macdonald et al., 2003; Reeves and de Wit, 2000; Brown et al., 1995). The latest models of the relative motion between the South American and the African plates suggest a diachronous opening of the 
South Atlantic, starting in the south and propagating to the north within a time span of 40 Myrs (Eagles, 2007).

The Orange Basin contains the stratigraphic record from lithospheric extension and rift tectonics throughout a fully evolved post-break-up setting, and thus provides an ideal area to study the evolution of a "passive" continental margin. The stratigraphy comprises a pre-rift successions (older than Late Jurassic, $>130 \mathrm{Ma}$ ), that is overlain by syn-rift deposits of Late Jurassic to Hauterivian age (131-116.5 Ma), and, in turn, by sediments of early drift stages up to Aptian age (113- $108 \mathrm{Ma}$ ). Non-restricted marine deposits of an Aptian to present day age overly the Pre-Aptian successions. The rift stage basin was characterised by the development of N-S oriented grabens and half-grabens trending approximately parallel to the rift axis, from near Walvis Bay to south of Cape Town (Gerrard and Smith, 1982). These graben structures were filled predominantly with siliciclastic continental and lacustrine rocks, and variable thicknesses of volcanic rocks (Brown et al., 1995). The syn-rift sequences rest unconformably on the Precambrian or Paleozoic basement and are unconformably overlain by Early Cretaceous to present post-rift successions. Lithologically the early post-rift successions comprise sandstone and shales, and the majority of the post-rift successions are claystones.

We present a 3D structural model the Orange Basin consistent with available seismic and lithologic well data, and validated this model using satellite gravity data to constrain the crustal structure of the basin.

\section{Data base and construction of a geological 3D model}

The study is based on results from seismic interpretation of 2D seismic lines recorded across the Orange Basin to a maximum of 6 seconds two-way travel 
time. Depth maps of interpreted horizons (Paton et al., 2007) were used in combination with the sequence stratigraphic framework established by previous studies (Brown et al., 1995; Muntingh, 1993; Muntingh and Brown, 1991) and data from 5 boreholes (including wire line logs, lithologies, vitrinite reflectance and biostratigraphy) to generate a 3D geological model. The interpreted horizons comprise a sequence of horizons from the near top-basement and the oldest lower drift horizon (6at1) through to the top of the drift succession, defined by the 22at1 horizon; these horizons correspond to an age range of $117.5 \mathrm{Ma}$ to $67 \mathrm{Ma}$ (Brown et al., 1995). Furthermore, between the basement and the drift horizons 5 syn-rift successions (SR-horizons cf. Table 1) were included, these were obtained from literature (Brown et al., 1995).

Information on the crustal structure underlying the basin sediments was available from the Springbok deep-seismic refraction experiment (Mahanyele et al., 2004) carried out approximately $100 \mathrm{~km}$ to the north of the study area (Fig. 1).

In addition, the free-air gravity anomaly and the bathymetry across the study area are extracted from Sandwell and Smith (1997) using the 1-min grid as a reference for the gravity modelling. The marine gravity field along the West African margin is characterised by an elongated, free-air anomaly parallel to the margin, known as the "edge-effect" anomaly (Fig. 2). This positive anomaly occurs just above the continental shelf break and is one of the most prominent features characterising the gravity field of offshore southwest Africa. Similar anomalies are observed at many passive continental margins and in particular along large parts of the conjugate margins of the Atlantic Ocean (Watts and Fairhead, 1999). The simplest configuration of an edge-effect anomaly is a positive "high" that correlates with the outer shelf, and a seaward "low". In 
many places an additional landward "low" is also linked with the gravity "high" (Watts and Fairhead, 1999).

Along the coast of West Africa the positive edge-effect anomaly displays variable characteristics. South of the Walvis Ridge, offshore Namibia, the character of the edge-effect anomaly is very diffuse and the gravity signal appears complex. Southwards, nearby the border with South Africa, the anomaly is expressed as a simpler "high-low" pair. Farther south, in the middle of the Orange Basin, this positive-negative couple can be observed clearly.

To construct the geological model, depth maps from seismic interpretation were interpolated using a minimum tension gridding algorithm to derive depth grids covering the entire study area. Subtraction of successive depth levels yielded the thickness of the geological units in-between. These 2D thickness grids of each unit were then integrated into a 3D geological model using the Geological Modelling System (GMS) developed at the GeoForschungsZentrum Potsdam (Scheck and Bayer, 1997). The model (Fig. 3) covers an area of $180 \mathrm{~km}$ in an eastwest direction and $130 \mathrm{~km}$ in a north-south direction, with a grid size of $58 \times 33$. This corresponds to a horizontal resolution of 3 by $4 \mathrm{~km}$. Vertically, the resolution of the model is defined by the 18 stratigraphic layers (Table 1, Fig. 3) and average physical properties are assigned to each layer. For the isostatic and gravimetric model calculations density is the decisive physical parameter. To derive realistic bulk densities for each layer a porosity-depth relationship combined with lithology-dependent matrix densities was assigned using well log information. Table 1 gives an overview of the densities used to construct the 3D model of the sediments, which in turn was used for isostatic crustal modelling to derive the position of the Moho beneath the basin. 


\section{Gravity modelling}

Three different models were tested to evaluate the influence of different crustal levels on the gravity field. The 18 layers of the geological model was reduced to 6 layers of significant density contrasts, by combining different layers of similar densities, to facilitate the gravity modelling.

As mentioned above, the seismic- and well data constrain the sedimentary cover of the study area. Once the geometry and density distribution in the sedimentary package were defined, different crustal configurations were investigated and tested against the observed gravity data. This was done in a 3 step procedure. First, the entire crust was treated as homogeneous and the variation of an average crustal density was tested. Second, the known densities of the sedimentary part were included to evaluate the gravity effect of the sediments. Third, realistic lateral variations of density in the middle and lower crust, based on information from the Springbok deep seismic refraction line, were incorporated to obtain a final gravity model that was compared to the observed gravity.

The software IGMAS was used for gravity modelling. IGMAS is an interactive, graphical computer system for the interpretation of potential field data by means of numerical simulations in 3D (Götze and Lahmeyer, 1988). Geologic structures are defined as polygons along parallel working planes; the triangulation between vertical planes is done automatically as well as the transformation from the 2D data input into the 3D model structure. Within the gravity models presented here the distance between each working planes is $25 \mathrm{~km}$. Successive and interactive modification of parameters along the working planes, either density or geometry or both, enables the user to create a model as realistic as possible. To 
avoid boundary effects the gravity models were extended to both sides of the study area. The reference density is $2.67 \mathrm{~g} / \mathrm{cm}^{3}$.

Finally, the algorithm based on triangulated polyhedrons is used for the calculation of the potential field resulting from the respective model (Götze and Lahmeyer, 1988).

\section{Isostatic model based on homogeneous crust}

The simple model considers a homogeneous crust; the only constraint is present day water depth. This model was calculated for an area beyond the constrained 3D geological model and covers the entire area shown in Figure 1. A depth position of the Moho was calculated with GMS assuming Airy isostasy. Airy's concept presumes static equilibrium with local compensation of the topography by buoyancy and gravitational forces (e.g. Fowler, 1990). The crust is considered as floating in a denser mantle. Buoyancy forces, based on Archimedes principle, act on the crust to equal the weight of displaced mantle material. Isostatic compensation is achieved within a homogeneous crust by varying the depth to the crust/mantle boundary (Moho). Thus, a change in crustal thickness and hence Moho topography, balances the masses. The resulting Moho depth for this simple model depends on the chosen average crustal density as well as on the assumed depth of isostatic compensation. Modelling is based on the comparison with a reference model defined as a crustal block with a given thickness and density that "sinks" into the mantle. Firstly, the equilibrium conditions for the reference model are calculated according to:

$$
\rho_{C} \cdot h_{C}=\rho_{M} \cdot h_{M}
$$

Where

$$
\rho_{\mathrm{c}}=\text { crustal density; } \quad \mathrm{h}_{\mathrm{c}}=\text { thickness of the crust; }
$$




$$
\rho_{\mathrm{M}}=\text { mantle density; } \quad \mathrm{h}_{\mathrm{M}}=\text { thickness of displaced mantle. }
$$

Secondly, the isostatic compensation is calculated for the model accounting for the present day water depth and the configuration of the sediments. Accordingly, a varying of the crustal thickness, and thus a change in the topography of the Moho, balances the masses:

$$
\rho_{c} \cdot h_{c}+\rho_{M} \cdot h_{M}=\rho_{W} \cdot h_{W}+\sum \rho_{S} \cdot h_{S}+\rho_{C} \cdot h_{C}+\rho_{M} \cdot h_{M}
$$

Where

$$
\begin{array}{ll}
\rho_{\mathrm{c}}=\text { crustal density; } & \mathrm{h}_{\mathrm{c}}=\text { thickness of the crust; } \\
\rho_{\mathrm{M}}=\text { mantle density; } & \mathrm{h}_{\mathrm{M}}=\text { thickness of displaced mantle; } \\
\rho_{\mathrm{w}}=\text { water density; } & \mathrm{h}_{\mathrm{w}}=\text { water depth; } \\
\rho_{\mathrm{s}}=\text { sediment density; } & \mathrm{h}_{\mathrm{s}}=\text { thickness of the sediments. }
\end{array}
$$

The base of the crust in the reference model corresponds to the compensation depth because at this level isostatic equilibration is achieved and below this depth all pressures are hydrostatic (e.g. Fowler, 1990). The compensation depth (cd) with respect to an Airy isostatic model, therefore, implies the depth of the deepest block (e.g. Sleep and Fuyita, 1997). The reference compensation depth is chosen to coincide with observations from the Springbok seismic refraction profile, where the greatest crustal thickness is about $35 \mathrm{~km}$ in the continental part of the profile. The first calculated model considers a compensation depth of $34 \mathrm{~km}$ and a mantle density of $3.3 \mathrm{~g} / \mathrm{cm}^{3}$. Crustal density is assumed to be homogeneous $\left(\rho_{\text {crust }}=2.75 \mathrm{~g} / \mathrm{cm}^{3}\right)$ and the position of the Moho is obtained from an isostatic calculation that balances the present day water depth. 
The resulting model (Fig. 4) shows a Moho position at a depth of $34 \mathrm{~km}$ in the eastern, landward part of the model. Westward, with increasing water depth, the Moho depth decreases. In the south-western part of the model, where the water depth reaches a maximum, the Moho shallows to less than $27 \mathrm{~km}$.

These findings are included into the IGMAS gravity modelling program to calculate the gravity response of this simple model. Along a cross-section through the 3D gravity model (Fig. 5), the calculated result is shown. The gravity response of the model in the east is a flat curve, similar to the observed gravity field. Although the signature of both curves is similar, the response of the model is not able to fit the observations, especially between 0 and $300 \mathrm{~km}$ along the profile.

To summarise, the simple model is able to reproduce the position of the edgeeffect anomaly, but does not match either its wavelength or its amplitude.

Applying a higher/lower average crustal density results in a proportional shift of the resulting Moho depth but yields the same gravity response of the model (cf. Fig. 6); it does not match observed variations.

Using a different depth of compensation does, however, result in a different gravity response. The responses for three different compensation depths, 30, 34 and $37 \mathrm{~km}$, using an average crustal density of $2.75 \mathrm{~g} / \mathrm{cm}^{3}$ and a mantle density of $3.3 \mathrm{~g} / \mathrm{cm}^{3}$ are shown in Figure 7.. The resulting geometry of the Moho, calculated in GMS, is the same for each applied depth, but shifted according to the new compensation depth. Not surprisingly, a compensation depth of $34 \mathrm{~km}$ results in a Moho depth that is $4 \mathrm{~km}$ deeper compared to a compensation depth of $30 \mathrm{~km}$, and $3 \mathrm{~km}$ shallower compared to a model of $37 \mathrm{~km}$ compensation depth. By comparing the resulting gravity fields two major features are obvious: (1) The three models differ only in the oceanward part of the model; and (2) all models 
reproduce the location of the observed anomaly but fail to match its magnitude. Oceanward all curves diverge within a range of -12 to $-20 \mathrm{mGal}$ but all converge above the shelf break. All density configurations result in the same shape of the edge effect anomaly with the same amplitude and wavelength.

\section{Isostatic model including sediments}

This Airy based model includes both the geometry and density of the sediment package that makes up to $18 \mathrm{~km}$ of the crust, but the (middle and lower) crust is treated as homogeneous. The Airy approach is applied, therefore, to the load distribution imposed by the present day water column and the sedimentary layers to derive the Moho depth. Again, different model configurations were tested. Densities for the crystalline crust were varied from $2.7 \mathrm{~g} / \mathrm{cm}^{3}$ to $2.85 \mathrm{~g} / \mathrm{cm}^{3}$. For the compensation depths values of 30,34 and $37 \mathrm{~km}$ were chosen. In Figure 8, the position of the Moho using a compensation depth of $34 \mathrm{~km}$ is shown for two end-member models with crustal densities of $2.7 \mathrm{~g} / \mathrm{cm}^{3}$ and $2.85 \mathrm{~g} / \mathrm{cm}^{3}$, respectively. The density difference between these two end member models results in the depth to the Moho of the deep water area being $6 \mathrm{~km}$ deeper than in a landward position. For a density of $2.7 \mathrm{~g} / \mathrm{cm}^{3}$ the Moho shallows to $25 \mathrm{~km}$, and for a density of $2.85 \mathrm{~g} / \mathrm{cm}^{3}$ a depth of $20 \mathrm{~km}$ is calculated.

Applying realistic density variations in the sedimentary part of the model results in an up to $5 \mathrm{~km}$ shallowing of the Moho compared to the simple model with a homogeneous crust.

The gravity response for a crustal density of $2.75 \mathrm{~g} / \mathrm{cm}^{3}$ and a compensation depth of $34 \mathrm{~km}$ is shown in Figure 9. In the oceanward part of the profile, where the observed gravity profile is flat, the response of the model fits the observations. At kilometre 260 along the profile, close to the shelf break, both 
curves converge and rise parallel to each other. In contrast, landward of kilometre 310, above the shelf break, the calculated and observed curves diverge and there is a significant mismatch between the calculated and the observed curves. Thus, this Airy model is able to reproduce the slope of the anomaly in its observed position, but not its wavelength or its amplitude.

To summarise, an Airy-based, isostatically balanced density model including a homogeneous mid to lower crust does not explain the observation of the edge effect anomaly. A mass excess adjacent to the shelf break is needed to resolve this effect.

\section{Final model considering a sediment cover and a complex crustal configuration}

A common strategy for density-modelling of the crystalline crust is to convert Pwave velocities measured in deep refraction seismic experiments to densities. The closest such deep refraction profile to the study area is the Springbok line (Mahanyele et al., 2004). Along this profile, the transitional lower crust between the oceanic and the continental crust is characterised by high P-wave velocities (> $7 \mathrm{~km} / \mathrm{s}$ ) and high densities $\left(>3.1 \mathrm{~g} / \mathrm{cm}^{3}\right)$. We used the Nafe-Drake curve (e.g. Ludwig et al., 1970) for sedimentary rocks and a correlation from Christensen and Mooney (1995) for igneous and metamorphic rocks (e.g. Fowler, 1990) to derive a grid-based density field from the velocity model.

In order to apply a similar structure to the 3D model, as found in the Springbok line, 6 different layers were defined to represent the middle and lower crust beneath the study area. The lateral density variations of these layers were allowed to range from 2.7 to $3.2 \mathrm{~g} / \mathrm{cm}^{3}$. Furthermore, with increasing depth densities also increase. Within the volume of the geological model the position of 
the Moho is inferred from the isostatic crustal model (reference model: $\left.\rho_{\text {crust }}=2.75 \mathrm{~g} / \mathrm{cm}^{3}, \mathrm{~cd}=34 \mathrm{~km}\right)$.

For the oceanward part of the gravity model we adopted the geometry observed in the Springbok seismic refraction profile. Although the Springbok line is at some distance $(\sim 100 \mathrm{~km})$ from the modelled area, we consider it reasonable to project the main features observed there into the working planes of the study area with the assumption that the margin is characterised by a similar $2 \mathrm{D}$ structural character along strike.

The configuration of this model was defined by the water column, the sedimentary part, an inhomogeneous middle and lower crust. The position of the Moho was derived from isostatic crustal modelling used in combination with findings from the Springbok line.

Figure 10 shows the working plane through the 3D density model with the respective measured and calculated gravity curves. In the oceanward part, the uppermost $10 \mathrm{~km}$ are made of regularly layered sediments and crustal units and the Moho occurs at a depth of $12.5 \mathrm{~km}$. Towards the shelf break, east of kilometre 290, the sediment layers reach their maximum thicknesses below the edge-effect anomaly where the middle and lower crust comprises 6 layers of different densities. At this location, the Moho depth increases to more than $30 \mathrm{~km}$, and the observed gravity anomaly reaches its maximum at the shelf break. A thick pile of sediments in the uppermost part of the model replaces much of the water body of the model and forces the calculated gravity curve to rise. In order to compensate for this effect, a higher density contrast is needed to decrease the curve towards the east. To achieve this, a high density body of up to $14 \mathrm{~km}$ thickness is required in the lower crust. Remarkably, farther east of kilometre $320 \mathrm{~km}$ along the profile the thickness of the high density body decreases 
abruptly. This corresponds to an increase in thicknesses of the adjacent lower density bodies. This change coincides with a decrease in the amplitude of the gravity curve. Across the entire 3D model area the high density body has an average thickness of $11 \mathrm{~km}$ along the strike of the anomaly, and locally is up to $14 \mathrm{~km}$ thick (Fig. 11). The body thins continuously oceanward, but is limited landwards by a sharp boundary against less dense crustal material.

This crustal model of the African continental margin reproduces the observed edge-effect not only along a single profile (Fig. 10), but also in 3 dimensions. Figure 12 shows a comparison of the measured gravity field and the calculated results in map view across the modelled area.

\section{Discussion}

Early models of the edge-effect anomaly fitted observations with an idealized continent-ocean transition. For example, the transition between thick continental crust and thin oceanic crust can produce an asymmetric anomaly (e.g. Sleep and Fuyita, 1997). Such an anomaly would be centred above the transition zone between oceanic and continental crust with a maximum above the continental part and a minimum above the oceanic portion. This model is very sensitive to the underlying geometry. In reality, this theoretical concept of an edge-effect anomaly is more complex. The most obvious reason for this is the load-effect of sediments on the thinned crust. In addition it is likely that crustal blocks are not completely compensated in terms of local isostasy. Walcott (1972) and Watts (1988) showed the importance of regional compensation and geologic processes (e.g. sedimentation and magmatism) involved in margin evolution. Watts (1988) proposed that the edge-effect anomaly resulted from all the processes operating at the margin, including rift structures and sediment 
loading. A "rifting anomaly" results from the margin geometry through its evolution without sediment loading and it consists of both a negative and a positive anomaly with a high located above the unstretched crust and a low above the stretched crust.

This type of anomaly can be reproduced by the simple model, as described above, when a homogeneous crust is affected by an increasing degree of thinning towards the ocean (Fig. 6,7). In such a configuration, water depth alone would balance crustal thinning. The position of the Moho shallows where the water deepens as more high density material must balance the low density water. Although the water load and a homogeneous crust create a curve similar to the edge-effect, the calculated gravity response of the model is shifted to lower gravity values. Consequently, the gravity response of the simple model suggests that this type of model is not applicable.

The sum effect of the sediments and the crust are investigated in a further refined model. Again, this model does not reproduce the required gravity decrease landward of the observed high, which is nevertheless observed in the data (Fig. 9). These isostatic Airy models do give information on a required crustal geometry based on a certain average crustal density. In detail, they fail to give information on the internal density distribution within the crust. The juxtaposition of the incorporated sediment pile and the homogeneous crust does not create a sufficient density contrast, either because the pile is not thick enough or the crust is not homogeneous. As the sediment thickness resolved in this model is quite large (up to $12 \mathrm{~km}$ ) and in the average range for continental margins, the misfits are more likely related to deep crustal heterogeneities. Indications for such variations in deep crustal structures come from seismic refraction data. The Springbok line, and other refraction profiles elsewhere reveal 
significant lateral variations in seismic velocity of the lower crust perpendicular to the passive margin as well as the presence of lower crustal high velocity bodies (e.g. Holbrook et al., 1994).

Bauer et al. (2000) have demonstrated that the observed edge-effect anomaly offshore Namibia is related to the superposition of topography effects and lateral density variations alone, but that the width and amplitude of the observed gravity anomaly requires dense material in the middle and lower crust.

Assuming a positive correlation between seismic velocity and density allows the construction of an improved gravity model that closely reproduces the edgeeffect anomaly (Fig. 10). Beside the geological model information, such a gravity model includes a heterogeneous middle and lower crust. In this model a high density body in the lower crust is spatially consistent with a high velocity body along the Springbok profile. The positive anomaly in this case appears to be a result of the juxtaposition of the high densities in the middle and lower crust at the continent-ocean transition and the lower densities of the continental crust. In our gravity model, this lower crustal body has a density of $3.2 \mathrm{~g} / \mathrm{cm}^{3}$ (and the respective $\mathrm{P}$-wave velocities are $>7.2 \mathrm{~km} / \mathrm{s}$ ). The high velocities and the modelled high densities suggest that this material is mafic in nature. Similar conclusions have been proposed for the Namibian margin by Stewart et al. (2000) and Gladczenko et al. (1998). In addition, these high density, high velocity bodies have also been found on other volcanic margins, for example the offshore eastern United States (Talwani and Abreu, 2000). In the North Atlantic the characteristic P-wave velocities commonly range within this zone from $7.1-7.7 \mathrm{~km} / \mathrm{s}$ (e.g. Eldholm et al., 2000; Gernigon et al., 2003). 
From this observation arises the question how to interpret the high velocity-high density body?

Offshore and onshore refraction and reflection seismic experiments in Namibia show that the zone of high average P-wave velocities $(>7 \mathrm{~km} / \mathrm{s})$ is situated directly beneath a wedge of seaward dipping reflectors (Bauer et al., 2000). These reflectors in the transition zone between continental and oceanic crust are interpreted to consist of basalt flows and intercalated sediments. A seaward thickening wedge has been drilled in the study area in well A-C1 and found to consist of mainly basaltic lavas (Gerrard and Smith, 1982). This seaward thickening wedge has been interpreted as corresponding to the coeval postulated seaward dipping reflectors, and to represent extensive basaltic volcanism during the rifting phase of continental break-up (Hinz, 1981; Eldholm et al., 1995). Along the Springbok seismic refraction profile, nearby the Namibian/South African border, a high velocity body $(>7 \mathrm{~km} / \mathrm{s})$ is present in the lower crust below this seaward dipping wedge.

Offshore Namibia, the high velocity body is interpreted to represent the intrusive counterpart of the seaward dipping reflector wedge. The base of this high velocity body correlates with the seismic Moho. Bauer et al. (2000) favour the interpretation of this zone to be completely underplated mafic igneous material (Holbrook et al., 1994), whilst alternative interpretations assume heavily intruded extended continental crust (White et al., 1987).

McKenzie (1978) proposed a passive rifting model for basin evolution. Lithospheric thinning is accompanied by upwelling of the asthenosphere to maintain the isostatic equilibrium. A few years later Foucher et al. (1982) put forward a model of melt generation as a result of passive asthenosphere upwelling. White and McKenzie (1989) generally agreed with Foucher's ideas 
and argue that lithospheric stretching and thinning results in passive upwelling of the asthenosphere to fill the created space. Large quantities of melts, therefore, are a product of the decompressional processes. But crucial components of this model are increased temperatures, involving a "hot" mantle plume leading to the formation of large quantities of magmatic rocks.

This excessive magmatism may result in the emplacement of a mafic material, at present preserved as high density, high velocity body. Features like the lower crustal body can be also explained in an alternative way.

Gernigon et al. (2004) suggest that melt volumes along continental margins can originate from mechanical processes alone, and do not require the coeval influence of an involved mantle plume. Assuming realistic thinning factors, they show with 2D numerical calculations that a mantle plume is not a pre-requisite to generate a volcanic margin. Moreover, volcanic margin formation may simply be a consequence of decompressional melt production. In these models the lithosphere is extended and thinned, while the crust is warmed and mantle material rises. This leads to decompressional melting in the head of the rising mantle material (van Wijk et al., 2001). Melt production is dependent on the assumed amount of extension. At low stretching factors $(\beta<2)$ little melt is produced. At high extension $(\beta>5)$ significant melting occurs during the breakup process in a depth range from 20 to $50 \mathrm{~km}$ (e.g. van Wijk et al., 2001; Gernigon et al., 2006).

However, if a plume is involved it would influence the volume of produced melt. The difference between melt produced by decompressional melting and by a plume is a function of the magnesium content of the melts.

Melt generated from abnormally hot mantle material (plume) has a higher concentration of magnesium in comparison to melt generated from normal 
mantle material. This enrichment in magnesium causes an increase of igneous rock velocities from $6.8 \mathrm{~km} / \mathrm{s}$ to $7.2 \mathrm{~km} / \mathrm{s}$ or higher (White and McKenzie, 1989). Trumbull et al. (2002) argue for a plume influence off Namibia, an area close to Walvis Ridge. They show that the high observed P-wave velocities in a depth range from $7-30 \mathrm{~km}$ can be modelled with a lower crust of magnesium-rich basaltic composition along two transects offshore Namibia. The enrichment in magnesium indicates increased mantle temperatures perhaps related to the coeval Tristan da Cunha Hotspot activity. In contrast, they find no indication for a plume influence in the south close to our study area.

Based on the analysis of P-wave velocities along the Springbok seismic refraction profile Trumbull et al. (2006) argue against the possibility that the high velocities in the lower crust are related to the influence of the Tristan da Cunha plume. The velocity structure in the lower crust corresponds to gabbros without elevated magnesium content. This is consistent with results obtained onshore, where compositional signatures found in dolerite dikes indicate the same conclusion. To summarise, the influence of a plume on the high velocity body appears to be less probable in the study area than farther north, offshore Namibia.

An interesting aspect concerning the geometry of the high density body within the gravity model is its sharp boundary against the "normal" crystalline continental crust. This is consistent with observations in the MAMBA seismic refraction experiments offshore Namibia where a strong velocity gradient represents the landward termination of an intrusive section, whereas the seaward edge is much more gradual (Bauer et al., 2000). The lack of a transition zone is used to support the idea that intruded igneous material causes this strong gradient rather than thinned and rifted continental crust which is heavily intruded. 


\section{Conclusions}

Three types of crustal models and the respective gravity response have been used to derive the crustal-scale density structure of the continental margin beneath the Orange Basin of the west coast of South Africa consistent with the observed edge-effect anomaly along this margin. Although modelling of potential field data always yields non-unique results, we have reduced the ambiguity to a significant degree by combining isostatic findings and gravimetric modelling with constraints from deep seismic refraction data.

We find that:

(1) An Airy-type compensation with a laterally homogeneous crust is only partly consistent with observed gravity data, though the edge-effect anomaly is reproduced in position.

(2) A similar model incorporating sediments to explain the gravity low landward of the edge-effect anomaly is also not sufficient to reduce the misfit between observed and modelled gravity. A density contrast caused by a $12 \mathrm{~km}$ thick sequence of sediments is insufficient to cause the observed anomaly.

(3) Only a model that considers the sedimentary pile and an inhomogeneous mid- and lower crust comprising a high density body $\left(3.2 \mathrm{~g} / \mathrm{cm}^{3}\right)$ of considerable thickness $(\sim 11 \mathrm{~km})$ holds a sufficient density contrast to reproduce the observed edge-effect anomaly.

The high density material is likely mafic in nature and related to magmatic activity during the break-up phase of continental margin formation.

\section{Acknowledgements}


This work has been done in the framework of INKABA yeAFRICA at the GeoForschungsZentrum Potsdam.

We are grateful for the constructive comments of the reviewers M. de Wit and R. Domoney.

Isostatic modelling was performed with the Geological Modelling System (GMS) developed at GeoForschungsZentrum Potsdam, Department Organic Geochemistry under the leadership of Prof. Dr. U. Bayer.

We thank H.-J. Götze and S. Schmidt, University of Kiel, for the 3D gravity modelling programme IGMAS.

Maps were plotted using GMT 4.0 (http://gmt.soest.hawaii.edu/).

This is INKABA yeAFRICA contribution number 21.

\section{Figure captions}

Figure 1: Bathymetric map of the continental margin offshore South Africa. The green line frames the study area and outlines the inferred 3D geological model constrained by interpreted seismic reflection lines (black lines). Black diamonds represent wells within the study area. The location of the Springbok seismic refraction profile is shown in addition with a red line.

Figure 2: Free air gravity field with positive "edge-effect" anomaly parallel to the margin (Sandwell and Smith, 1997).The Location of the on- and offshore seismic refraction line is shown with a red line, and the bold black line encompasses the study area. 
Table 1: Overview of seismic horizons interpreted from seismic reflection data and the inferred layers in the 3D geological and gravity model, together with porosities and assigned densities.

Figure 3: 3D geological model comprising the study area with 18 assigned layers from the interpretation of seismic lines and well data.

Figure 4: Moho position for the simple case model considering a homogenous crust and present day water depth. The crustal density is $2.75 \mathrm{~g} / \mathrm{cm}^{3}$, mantle density is $3.3 \mathrm{~g} / \mathrm{cm} 3$ and the compensation depth is $34 \mathrm{~km}$ in the reference model. The black outline shows the area covered by seismic reflection data.

The blue dotted line is the working plane shown in Fig. 5,6,7,9,10. Map is in UTM coordinates (kilometres), Zone -33 S.

Figure 5: Gravity response for the simple case model: $\rho_{\text {crust }}=2.75 \mathrm{~g} / \mathrm{cm}^{3}$, $\rho$ mantle $=3.3 \mathrm{~g} / \mathrm{cm}^{3}, \mathrm{~cd}=34 \mathrm{~km}$.

Figure 6: Compilation of all simple case models for a constant compensation depth of $34 \mathrm{~km}$, but a range of crustal densities $\left(2.70,2.75,2.80\right.$ and $\left.2.85 \mathrm{~g} / \mathrm{cm}^{3}\right)$. Different crustal densities result in changing Moho depths (brownish colours), but result in the same respective calculated gravity response.

Figure 7: Compilation of all simple case models for a constant crustal density of $2.75 \mathrm{~g} / \mathrm{cm}^{3}$, but a range of depth to Moho according to different compensation depths $(30,34$ and $37 \mathrm{~km})$ and the respective calculated gravity response. 
Figure 8: Moho position for 2 end-member models: a) crustal density of 2.7 $\mathrm{g} / \mathrm{cm}^{3}$; b) $2.85 \mathrm{~g} / \mathrm{cm}^{3}$ including the geometry of sediments for a compensation depth of $34 \mathrm{~km}$ in both cases. Maps are in UTM coordinates (kilometres), Zone $33 \mathrm{~S}$.

Figure 9: Gravity modelling including the geometry of sediments (for a reference model $\rho_{\text {crust }}=2.75 \mathrm{~g} / \mathrm{cm}^{3}, \rho_{\text {mantle }}=3.3 \mathrm{~g} / \mathrm{cm}^{3}$, and $\mathrm{cd}=34 \mathrm{~km}$ ).

Figure 10: Final model, incorporating an inhomogeneous middle and lower crustal structure.

Figure 11: Thickness (in kilometres) of the high density body $(3.2 \mathrm{~g} / \mathrm{cm} 3)$ in the lower crust across the 3D geological model derived from gravity modelling. Map is in UTM coordinates (kilometres), Zone -33 S.

Figure 12: Comparison of measured versus calculated gravity field (interactive working planes are shown as diagonal lines). The red line is the working plane shown in previous figures. 
Bauer, K., Neben, S., Schreckenberger, B., Emmermann, R., Hinz, K., Fechner, N., Gohl, K., Schulze, A., Trumbull, R. B., and Weber, K. (2000): Deep structure of the Namibia continental margin as derived from integrated geophysical studies. Journal of Geophysical Research, B, Solid Earth and Planets 105, 25,829-25,853.

Brown, L. F., Jr., Benson, J.M., Brink, G.J., Doherty, S., Jollands, A., Jungslager, E.H.A., Keenan, J.H.G., Muntingh, A., and van Wyk, N.J.S. (1995): Sequence stratigraphy in offshore South African divergent basins: an atlas on exploration for Cretaceous lowstand traps by SOEKOR (Pty) Ltd.: American Association of Petroleum Geologists, Studies in Geology 41, 184 p.

Christensen, N. I., and Mooney, W. D. (1995): Seismic velocity structure and composition of the continental crust: a global view. Journal of Geophysical Research 100, 9761-9788.

Eagles, G. (2007): New angles on South Atlantic opening. Geophysical Journal International 168, 353-361.

Earth Vision 6.0, Dynamic Graphics Ltd. (http://www.dgi.com/).

Eldholm, O., Gladczenko, T. P., Skogseid, J., and Planke, S. (2000): Atlantic volcanic margins: a comparative study: Dynamics of the Norwegian margin, Geological Society of London, Special Publications, London, 411-428.

Eldholm, O., Skogseid, J., Planke, S., and Gladczenko, T. P. (1995): Volcanic margin concepts. In E. Banda, Talwani, M. \& Torné, M. (Editors): Rifted Ocean-Continent Boundaries, NATO/ARW Series, Kluwer Academic Publishers, 1-16.

Foucher, J.-P., Le Pichon, X.,Sibuet, J.-C. , Roberts, D. G. ,Chenet, P.-Y. ,Bally, A. W. ,Oxburgh, E. R. , Kent, P.,Dewey, J. F. ,Bott, M. H. P. ,Jackson, J. A. ,Osmaston, M. F. ,Turcotte, D. L. (1982): The ocean-continent transition in the uniform lithospheric stretching model; Role of partial melting in the mantle: Philosophical Transactions of the Royal Society of London. Series A, Mathematical and Physical Sciences, Royal Society of London, London, 27-43.

Fowler, C. M. R. (1990): The Solid Earth: an introduction to global geophysics. Cambridge University Press, Cambridge, 490 p. 
Gernigon, L., Lucazeau, F., Brigaud, F., Ringenbach, J. C., Planke, S., and Le Gall, B. (2006): A moderate melting model for the Vøring margin (Norway) based on structural observations and a thermo-kinematical modelling: Implication for the meaning of the lower crustal bodies. Tectonophysics 412, 255-278.

Gernigon, L., Ringenbach, J.-C., Planke, S., and Le Gall, B. (2004): Deep structures and breakup along volcanic rifted margins: insights from integrated studies along the outer Vøring Basin (Norway). Marine and Petroleum Geology 21, 363-372.

Gernigon, L., Ringenbach, J. C., Planke, S., Le, G. B., and Jonquet, K. H. (2003):

Extension, crustal structure and magmatism at the outer Voring Basin, Norwegian margin. Journal of the Geological Society of London 160, 197-208.

Gerrard, I., and Smith, G. C. (1982): Post-Paleozoic succession and structure of the southwestern African continental margin. In J. S. Watkins, Drake, C.L. (Editors): Studies in Continental Margin Geology, American Association of Petroleum Geologists Memoir 34, 49-74.

Gladczenko, T. P., Skogseid, J., Eldholm, O. (1998): Namibia volcanic margin. Marine Geophysical Researches 20, 313-341.

Goetze, H. J., and Lahmeyer, B. (1988): Application of three-dimensional interactive modeling in gravity and magnetics. Geophysics 53, 1096-1108.

Hinz, K. (1981): Hypothesis on terrestrial catastrophes: wedges of very thick oceanward dipping layers beneath passive continental margins - their origins and paleoenvironmental significance. Geologisches Jahrbuch, Series E 22, 1-28.

Holbrook, W. S., Reiter, E. C., Purdy, G. M., Sawyer, D., Stoffa, P. L., Austin, J. A., Jr., Oh, J., and Makris, J. (1994): Deep structure of the U.S. Atlantic continental margin, offshore South Carolina, from coincident ocean bottom and multichannel seismic data. Journal of Geophysical Research, B, Solid Earth and Planets 99, 9155-9178.

Ludwig, W. J., Nafe, J. E., and Drake, C. L. (1970): Seismic refraction, In A. E. Maxwell (Editors): The Sea, Wiley-Interscience, New York, pp. 53-84. 
Macdonald, D., Gomez, P. I., Franzese, J., Spalletti, L., Lawver, L., Gahagan, L., Dalziel, I., Thomas, C., Trewin, N., Hole, M., and Paton, D. (2003): Mesozoic break-up of SW Gondwana: implications for regional hydrocarbon potential of the southern South Atlantic. Marine and Petroleum Geology 20, 287-308.

Mahanyele, P. J., Bauer, K., Franke, D., Schulze, A., Ryberg, T., De Beer, C. H., Neben, S., Schreckenberger, B., Stettler, E. H., and Weber, M. H. (2004): How far to the south does the volcanic margin of Southwest Africa extend? An initial velocity model for the ocean-continent transition in the southern Cape Basin. 64 . Jahrestagung der Deutschen Geophysikalischen Gesellschaft, Berlin, 8-12 March, 2004. Abstract volume, 443-444.

McKenzie, D. (1978): Some remarks on the development of sedimentary basins. Earth and Planetary Science Letters 40, 25-32.

Muntingh, A., Brown, L.F. Jr. (1993): Sequence stratigraphy of the petroleum plays, postrift Cretaceous rocks (lower Aptian to upper Maastrichtian), Orange Basin, western offshore, South Africa. In P. Weimer, Posamentier, H.W. (Editors): Siliclastic Sequence Stratigraphy - recent developments and applications, American Association of Petroleum Geologists Memoir 58, Tulsa, pp. 71-97.

Muntingh, A. (1993): Geology, prospects in Orange Basin offshore western South Africa. Oil and Gas Journal 91, 106-109.

Paton, D. A., van der Spuy, D., di Primio, R., Horsefield, B. (in press.): Tectonically induced adjustment of passive margin accomodation soace; influence on the hydrocarbon potential of the Orange Basin, South Africa. American Association of Petroleum Geologists Bulletin

Reeves, C., and de Wit, M. (2000): Making ends meet in Gondwana: retracing the transforms of the Indian Ocean and reconnecting continental shear zones. Terra Nova 12, 272-280.

Sandwell, D. T., and Smith, W. H. F. (1997): Marine gravity anomaly from Geosat and ERS 1 satellite altimetry. Journal of Geophysical Research, B, Solid Earth and Planets 102, 10,039-10,054. 
Scheck, M., and Bayer, U. (1997): Configuration of the crust below the intracratonic Northeast German Basin. Terra Nostra 97/11, 121-125.

Sleep, N. H., and Fuyita, K. (1997): Principles of Geophysics. Blackwell Science., Malden, 586 p.

Stewart, J., Watts, A. B., and Bagguley, J. G. (2000): Three-dimensional subsidence analysis and gravity modelling of the continental margin offshore Namibia. Geophysical Journal International 141, 724-746.

Talwani, M., and Abreu, V. (2000): Inferences regarding initiation of oceanic crust formation from the U.S. East Coast Margin and conjugate South Atlantic margins. In W. Mohriac, Talwani, M. (Editors): Atlantic rifts and continental margins, American Geophysical Union, Washington. 211-233.

Trumbull, R. B., Sobolev, S. V., and Bauer, K. (2002): Petrophysical modeling of high seismic velocity crust at the Namibian volcanic margin. In M. A. Menzies, Klemperer, S.L., Ebinger, C.J., Baker, J. (Editors): Volcanic rift margins, Geological Society of America (GSA), Boulder. 221-230

van Wijk, J. W., Huismans, R. S., ter Voorde, M., and Cloetingh, S. A. P. L. (2001): Melt generation at volcanic continental margins; no need for a mantle plume? Geophysical Research Letters 28, 3995-3998.

Walcott, R. I. (1972): Gravity, Flexure, and the Growth of Sedimentary basins at a Continental Edge. Bulletin of the Geological Society of America 83, 1845-1848.

Watts, A. B. (1988): Gravity anomalies, crustal structure and flexure of the lithosphere at the Baltimore Canyon Trough (Atlantic). Earth and Planetary Science Letters 89, 221-238.

Watts, A. B., Fairhead, J.D. (1999): A process-oriented approach to modeling the gravity signature of continental margins. The Leading Edge 18, 258-263.

White, R., and McKenzie, D. (1989): Magmatism at rift zones - The generation of volcanic continental margins and flood basalts. Journal of Geophysical Research 94, 7685-7729. 
White, R. S., Spence, G.D., Fowler, S.R., McKenzie, D.P., Westbrook, G.K., Bowen, A.N. (1987): Magmatism at rifted continental margins. Nature 330, 439-444. 


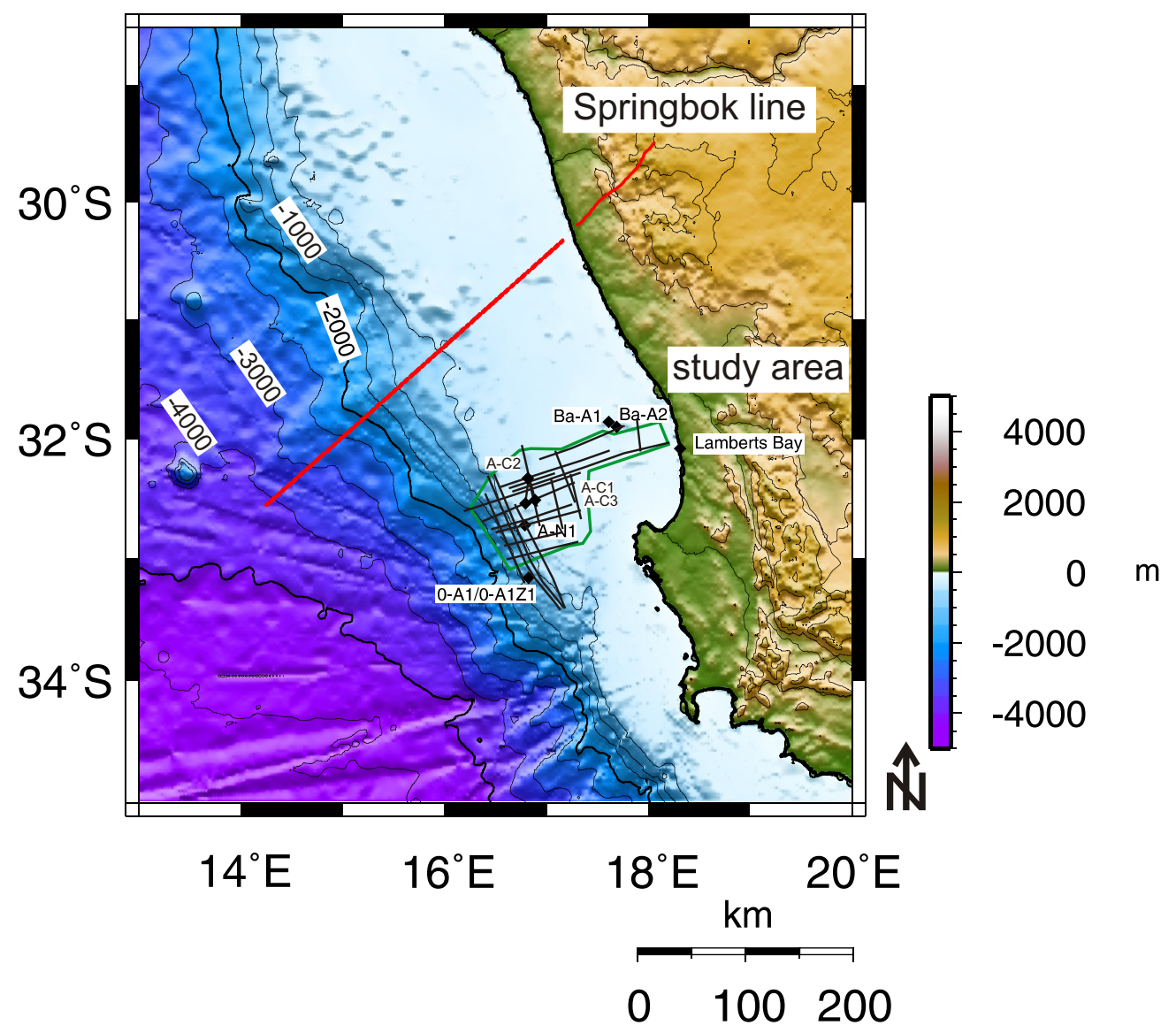

Figure 1: Bathymetric map of the continental margin offshore South Africa. The green line frames the study area and outlines the inferred 3D geological model constrained by interpreted seismic reflection lines (black lines). Black diamonds represent wells within the study area. The location of the Springbok seismic refraction profile is shown in addition with a red line. 


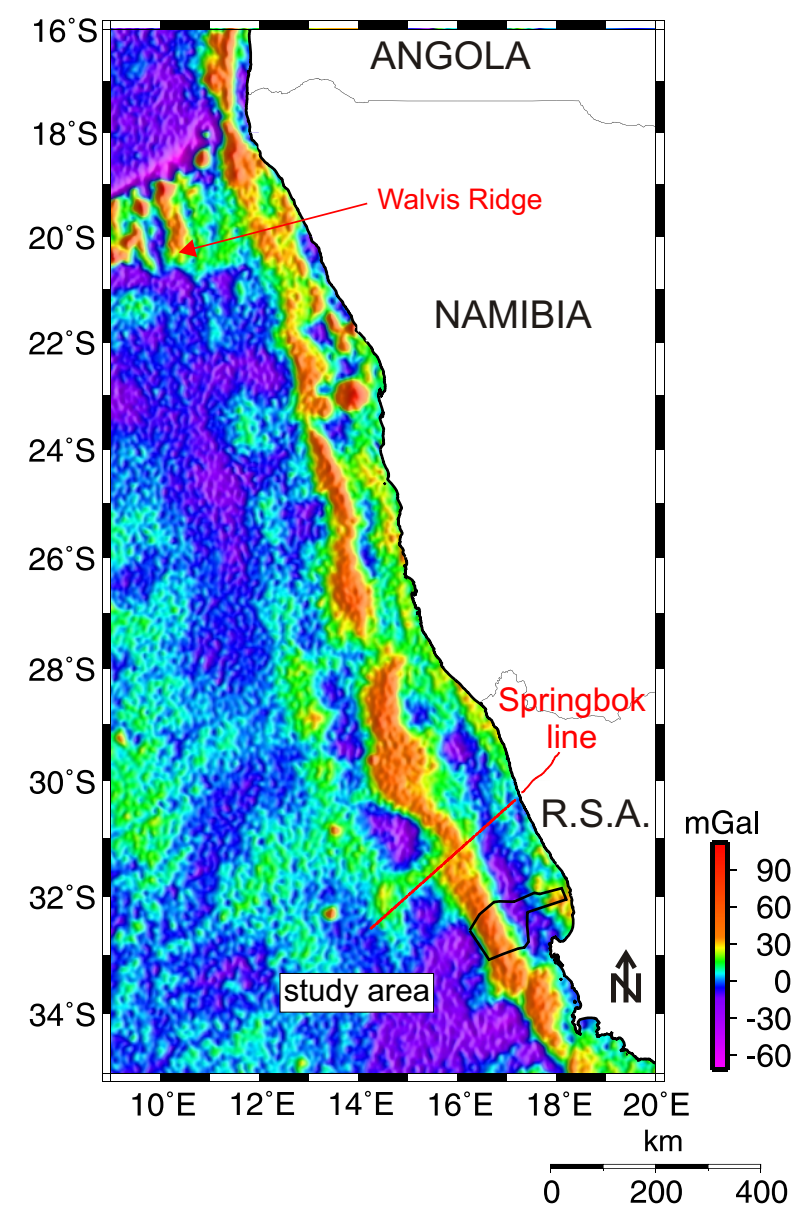

Figure 2: Free air gravity field with positive "edge-effect" anomaly parallel to the margin (Sandwell and Smith, 1997).The Location of the on- and offshore seismic refraction line is shown with a red line, and the bold black line encompasses the study area. 


\begin{tabular}{|c|c|c|c|c|c|}
\hline $\begin{array}{c}\text { seismic } \\
\text { horizons }\end{array}$ & $\begin{array}{c}\text { assigned } \\
\text { 3D model } \\
\text { layers }\end{array}$ & $\begin{array}{l}\text { porosity } \\
\varphi_{0}[\%]\end{array}$ & $\begin{array}{l}\text { density } \\
\rho\left[\mathrm{g} / \mathrm{cm}^{3}\right]\end{array}$ & $\begin{array}{l}\text { densities } \\
\text { for the } \\
\text { gravity } \\
\text { modelling }\end{array}$ & lithologies \\
\hline \multirow{5}{*}{$\begin{array}{r}\text { post22at1 } \\
22 a t 1 \\
\text { pre22at1 }\end{array}$} & mwater & & & & \\
\hline & $\mathrm{m} 18$ & $\sim 70$ & 1.7 & \multirow[b]{2}{*}{1.80} & \multirow[b]{3}{*}{ clay } \\
\hline & $\mathrm{m} 17$ & $\sim 50$ & 1.81 & & \\
\hline & m16 & $\sim 50$ & 1.9 & & \\
\hline & $\mathrm{m} 15$ & $\sim 40$ & 2.15 & \multirow[b]{2}{*}{2.30} & stone \\
\hline \multirow{2}{*}{$\begin{array}{l}\text { 16at1 } \\
15 a t 1\end{array}$} & $\mathrm{~m} 14$ & $\sim 35$ & 2.25 & & \multirow[b]{2}{*}{ 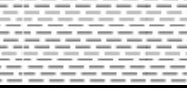 } \\
\hline & $\mathrm{m} 13$ & $\sim 27$ & 2.4 & & \\
\hline \multirow{3}{*}{ 14ht1 } & $\mathrm{m} 12$ & $\sim 22$ & 2.5 & \multirow{2}{*}{2.52} & \multirow{2}{*}{$\begin{array}{l}\text { silty } \\
\text { sandstone }\end{array}$} \\
\hline & $\mathrm{m} 11$ & $\sim 18$ & 2.54 & & \\
\hline & $\mathrm{m} 10$ & $\sim 16$ & 2.6 & \multirow{2}{*}{260} & \multirow{5}{*}{ sandstone } \\
\hline \multirow{2}{*}{$\begin{array}{l}\text { 13ht1 } \\
\text { 13at1 }\end{array}$} & $\mathrm{m} 9$ & $\max .12$ & 2.6 & & \\
\hline & $\mathrm{m} 8$ & 10 & 2.61 & \multirow{8}{*}{261} & \\
\hline \multirow{3}{*}{$\begin{array}{l}\text { Hauter } \\
\text { SR1upper }\end{array}$} & $\mathrm{m} 7$ & 10 & 2.62 & & \\
\hline & $\mathrm{m} 6$ & 10 & 2.62 & & \\
\hline & $\mathrm{m} 5$ & 10 & 2.62 & & \\
\hline \multirow{4}{*}{$\begin{array}{l}\text { SR1lower } \\
\text { SR2upper } \\
\text { SR2lower } \\
\text { SR3upper }\end{array}$} & $\mathrm{m} 4$ & 10 & 2.62 & & \\
\hline & m3 & 10 & 2.62 & & \\
\hline & $\mathrm{m} 2$ & 10 & 2.62 & & \\
\hline & $\mathrm{m} 1$ & 10 & 2.62 & & \\
\hline
\end{tabular}

Table 1: Overview of seismic horizons interpreted from seismic reflection data and the inferred layers in the 3D geological and gravity model, together with porosities and assigned densities. 


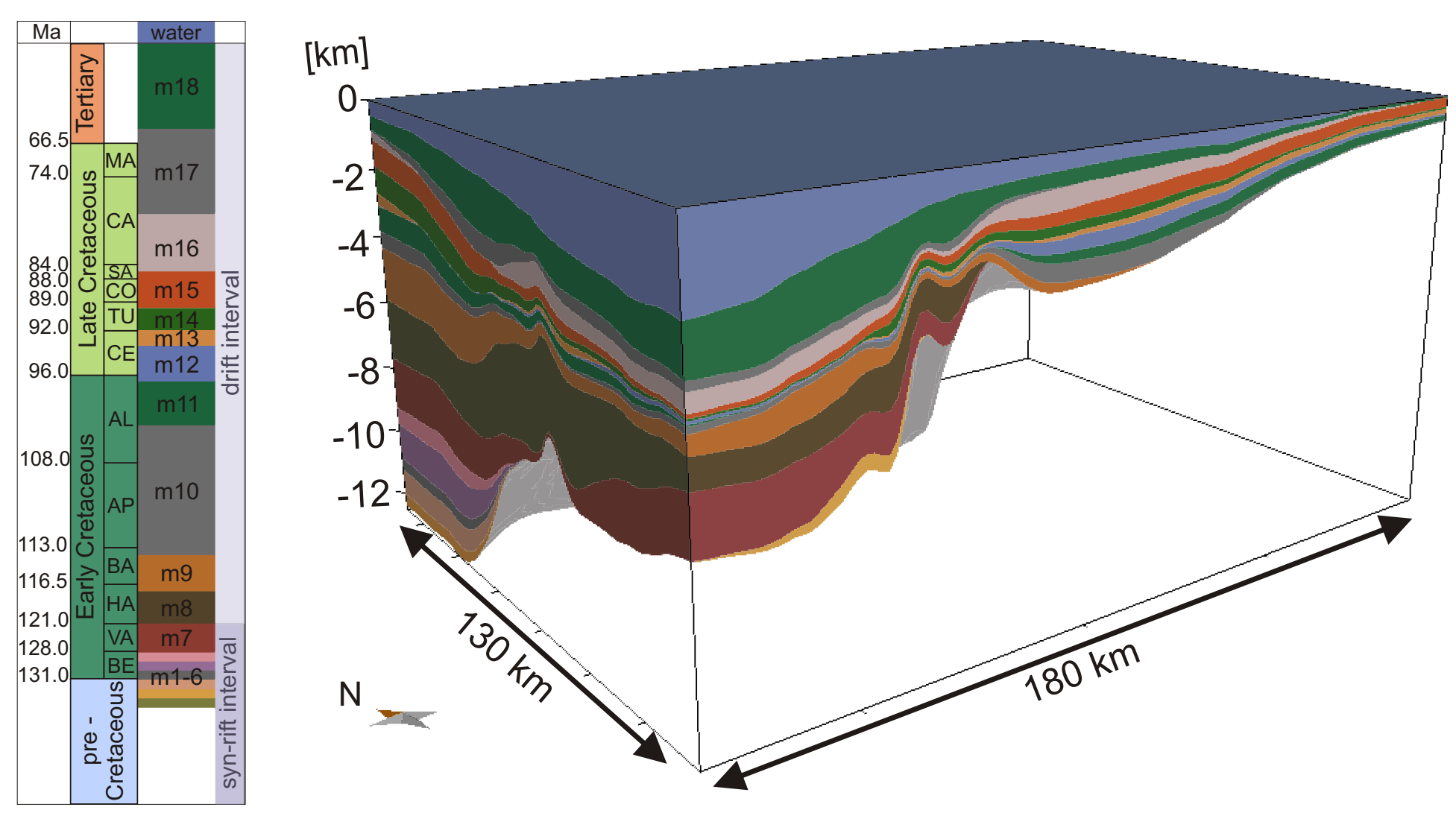

Figure 3: 3D geological model comprising the study area with 18 assigned layers from the interpretation of seismic lines and well data. 


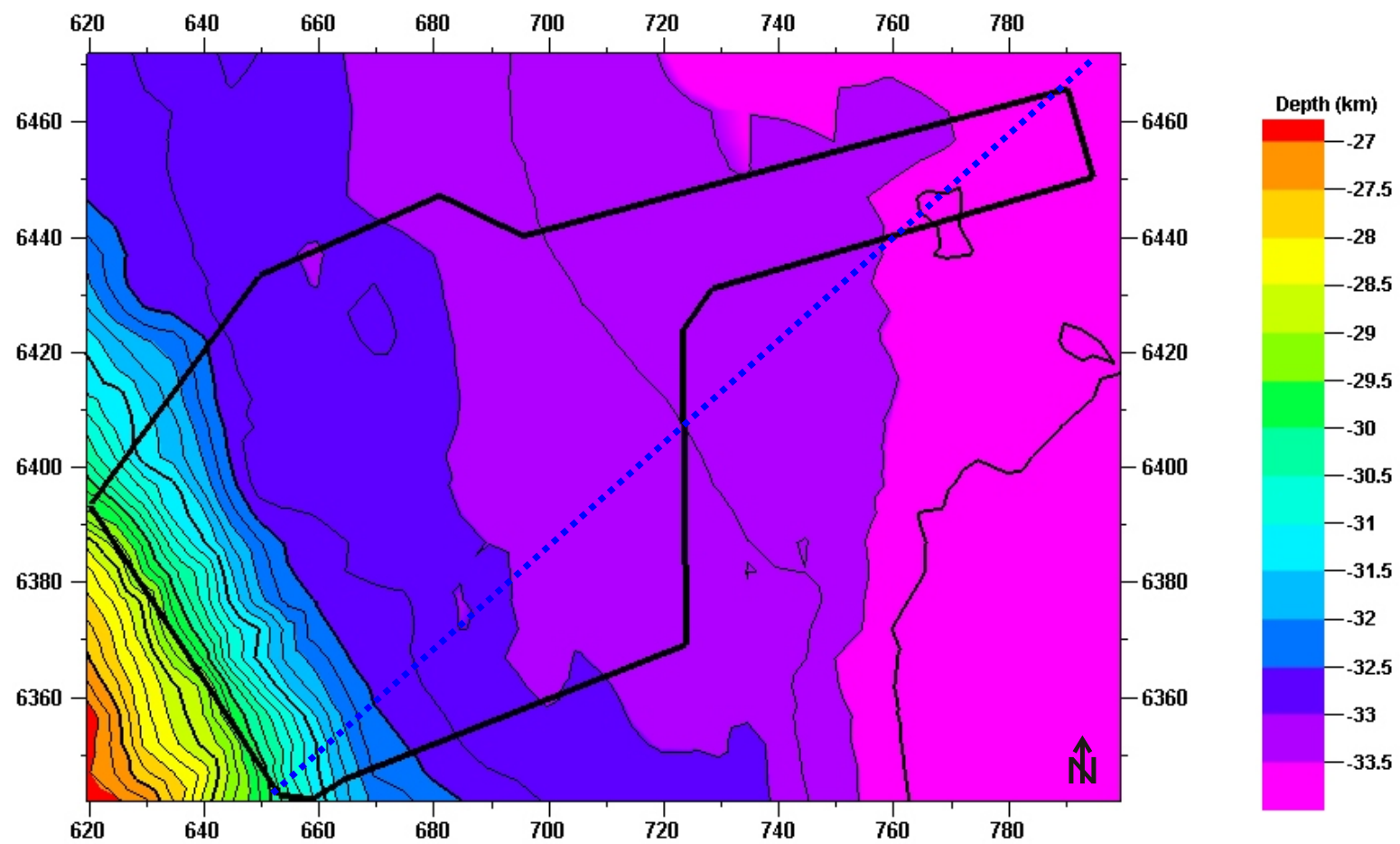

Figure 4: Moho position for the simple case model with a homogenous crust. The crustal density is $2.75 \mathrm{~g} / \mathrm{cm}^{3}$, mantle density is $3.3 \mathrm{~g} / \mathrm{cm}^{3}$ and the compensation depth is $34 \mathrm{~km}$ in the reference model. The black outline shows the area covered by seismic reflection data. With the cross section (blue dotted line) are results in gravity modelling presented. Map is in UTM coordinates (kilometres), Zone-33S. 


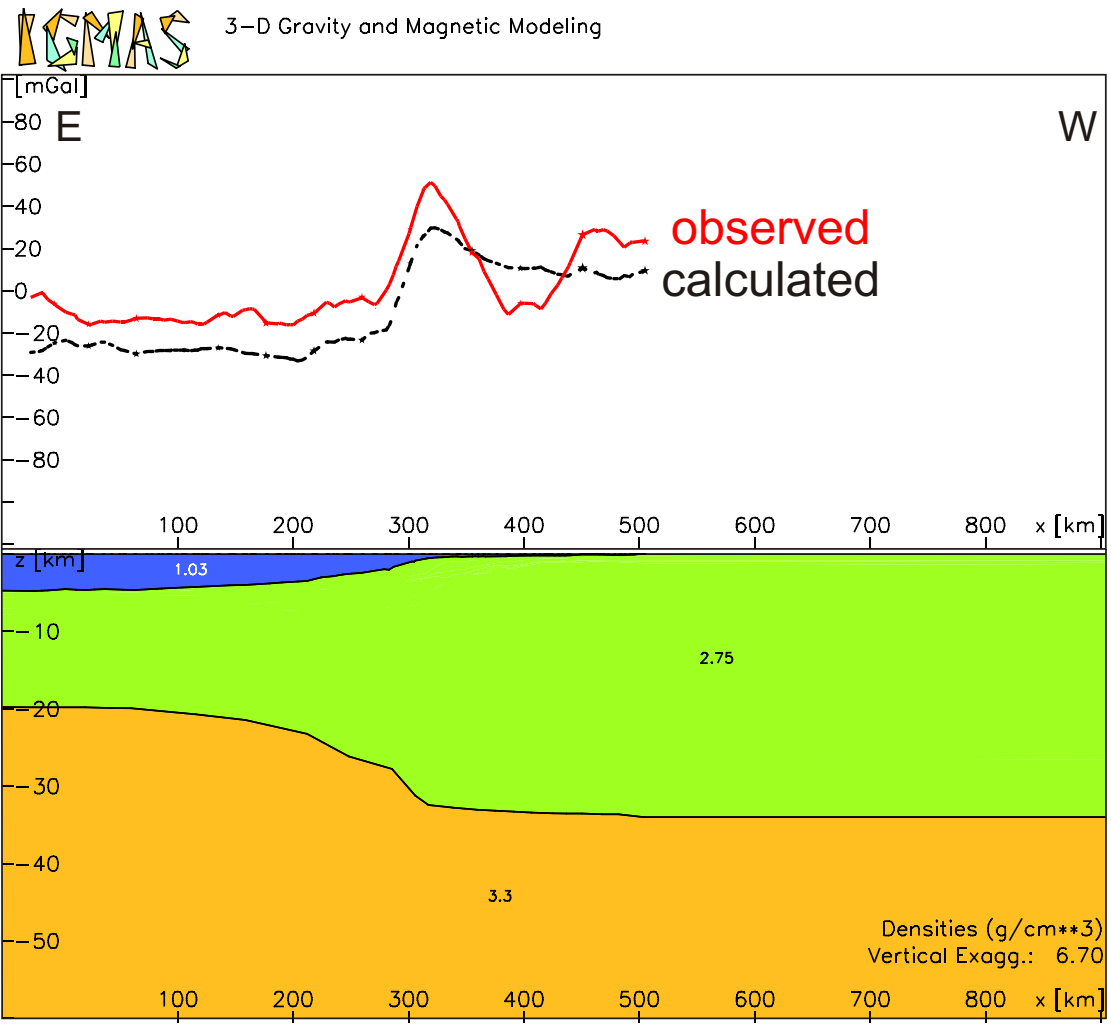

Figure 5: Gravity response for the simple case model: $\rho_{\text {crust }}=2.75 \mathrm{~g} / \mathrm{cm}^{3}, \rho_{\text {mantle }}=3.3 \mathrm{~g} / \mathrm{cm}^{3}, \mathrm{~cd}=$ $34 \mathrm{~km}$. 


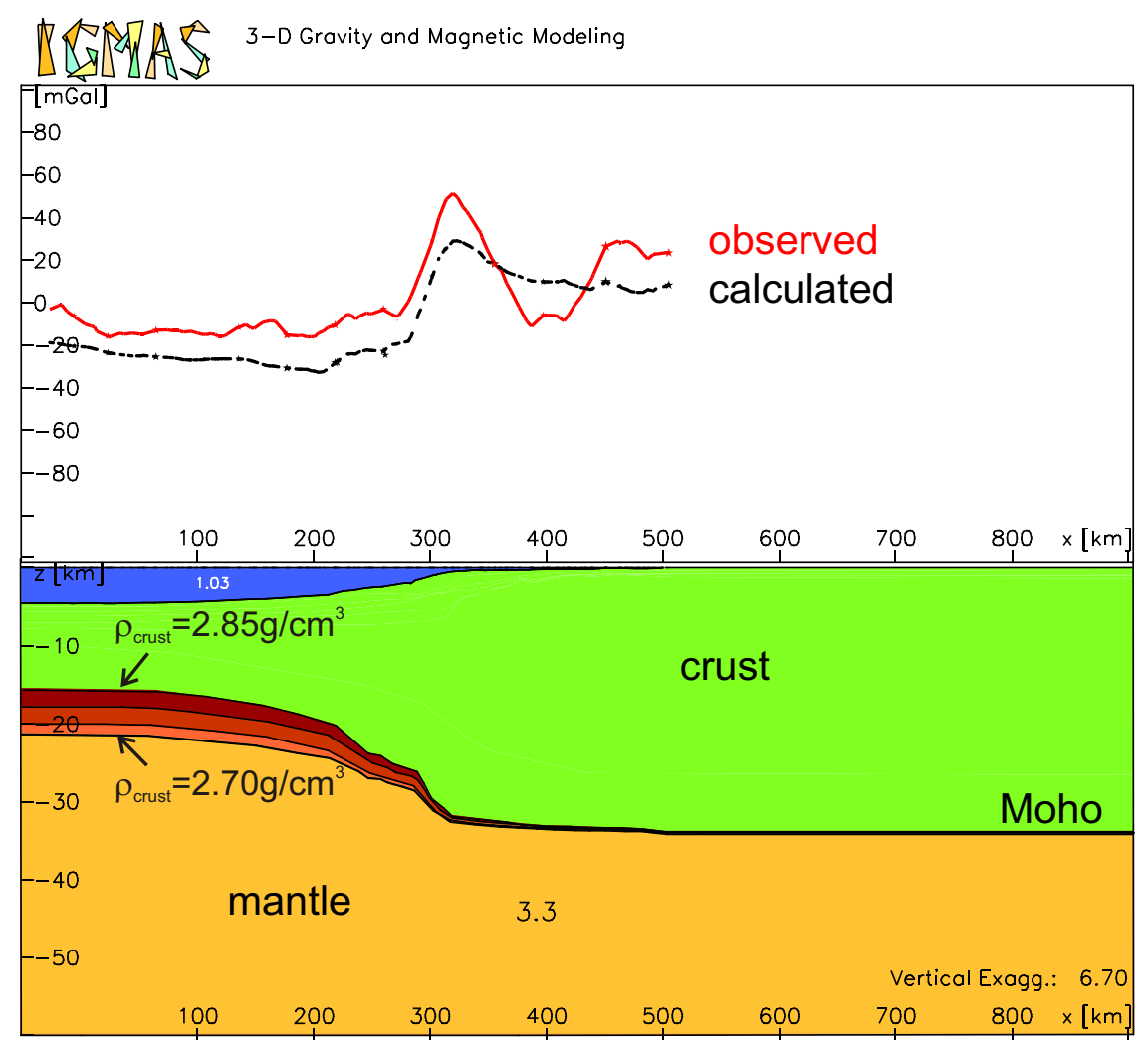

Figure 6: Compilation of all simple case models for a constant compensation depth of 34 $\mathrm{km}$, but a range of crustal densities $\left(2.70,2.75,2.80\right.$ and $\left.2.85 \mathrm{~g} / \mathrm{cm}^{3}\right)$. Different crustal densities result in changing Moho depths (brownish colours), but result in the same respective calculated gravity response. 


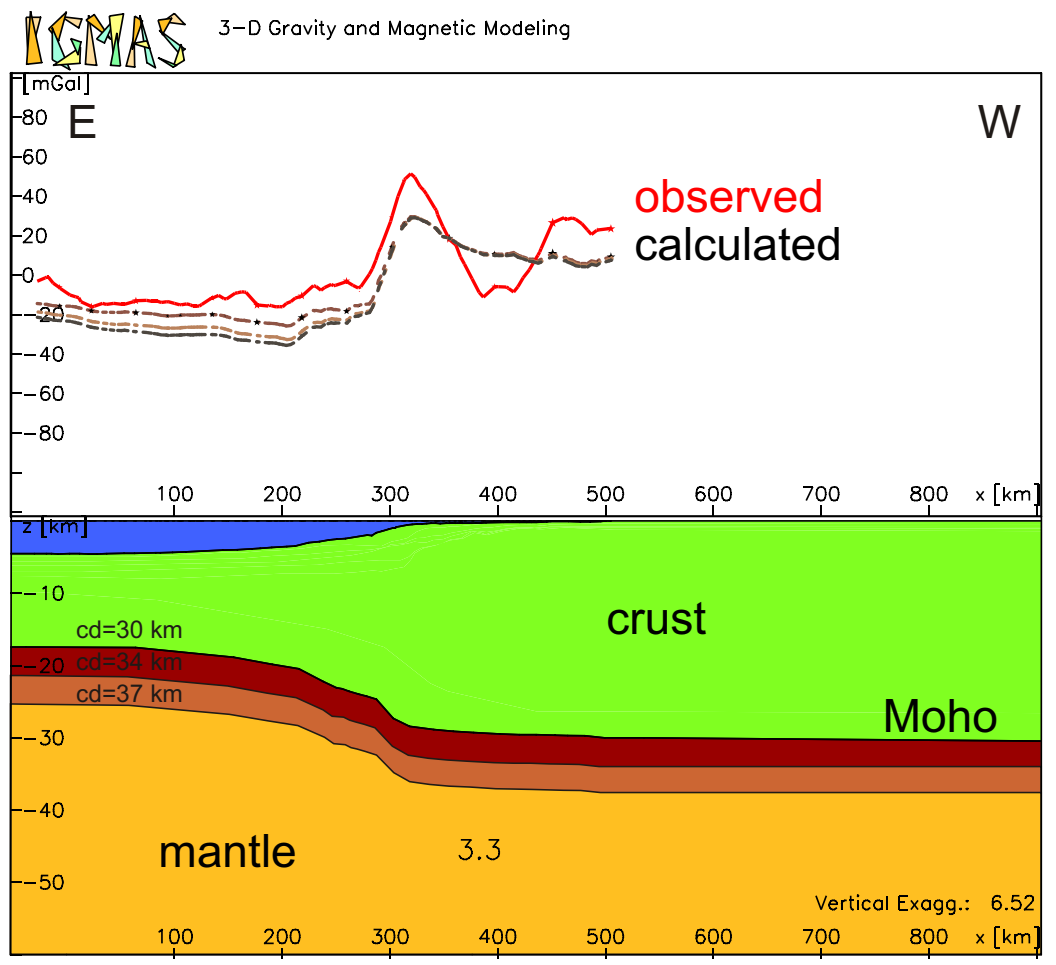

Figure 7: Compilation of all simple case models for a constant crustal density of $2.75 \mathrm{~g} / \mathrm{cm}^{3}$, but a range of depth to Moho according to different compensation depths (30, 34 and $37 \mathrm{~km}$ ) and the respective calculated gravity response. 
(a)

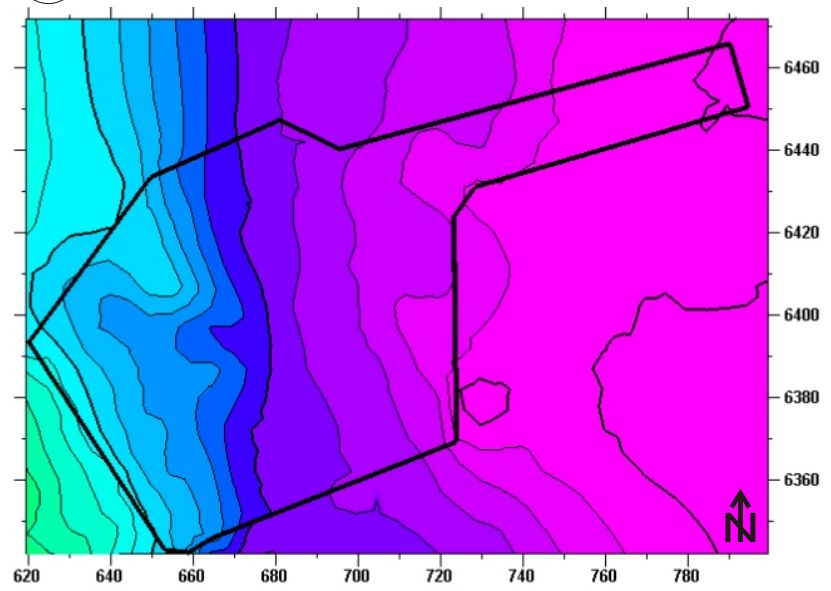

(b)

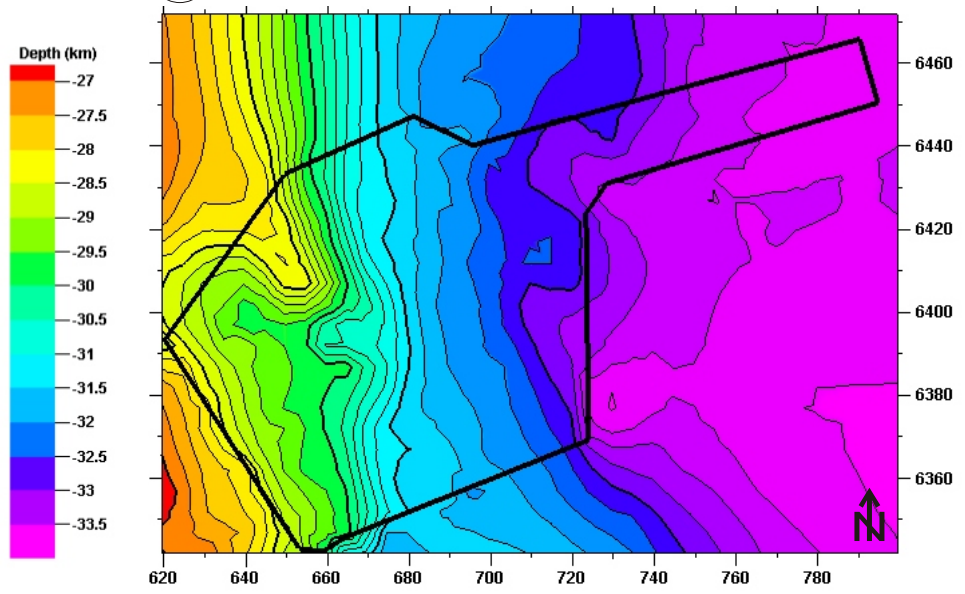

Figure 8: Moho position for 2 end-member models: a) crustal density of $\left.2.7 \mathrm{~g} / \mathrm{cm}^{3} ; \mathrm{b}\right) 2.85 \mathrm{~g} / \mathrm{cm}^{3}$ including the geometry of sediments for a compensation depth of $34 \mathrm{~km}$ in both cases. Maps are in UTM coordinates (kilometres), Zone -33S. 


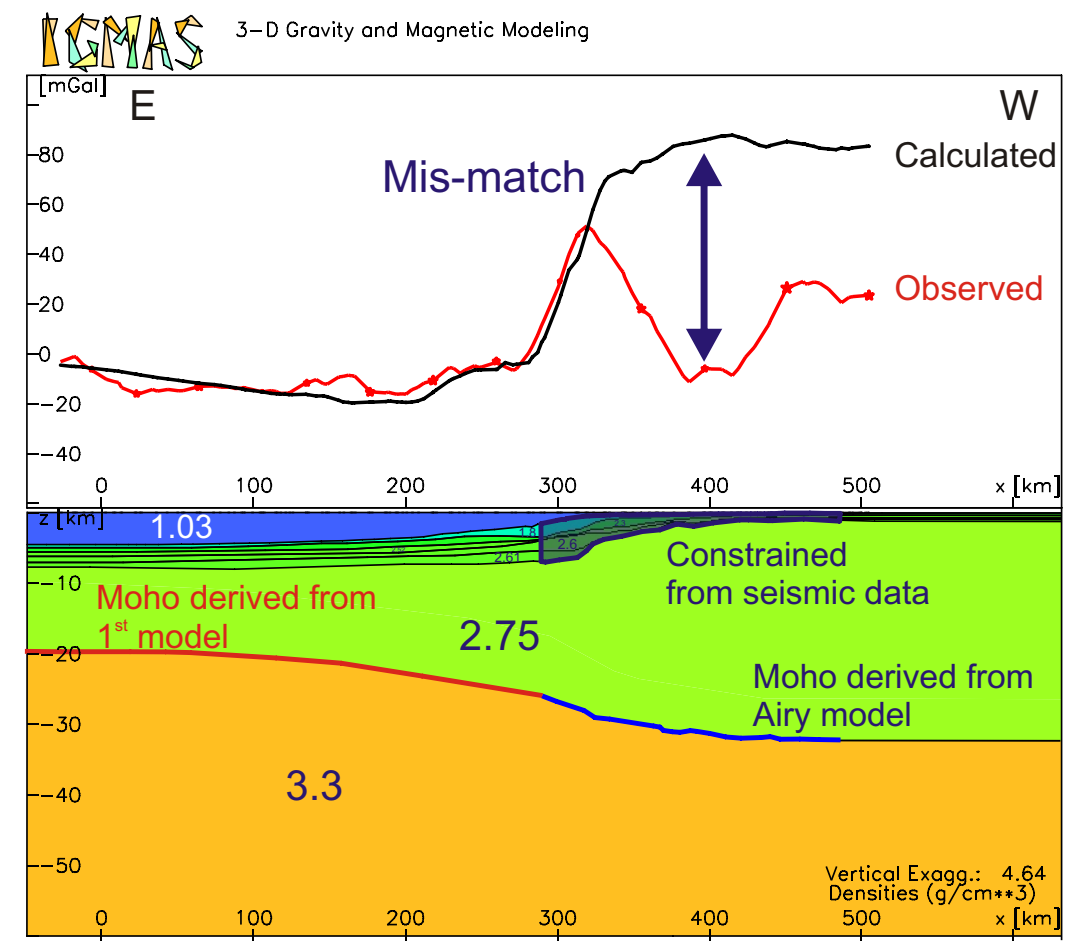

Figure 9: Gravity modelling including the geometry of sediments (for a reference model $\rho_{\text {crust }}=2.75 \mathrm{~g} / \mathrm{cm}^{3}, \rho_{\text {mantle }}=3.3 \mathrm{~g} / \mathrm{cm}^{3}$, and cd= $=34 \mathrm{~km}$ ). 


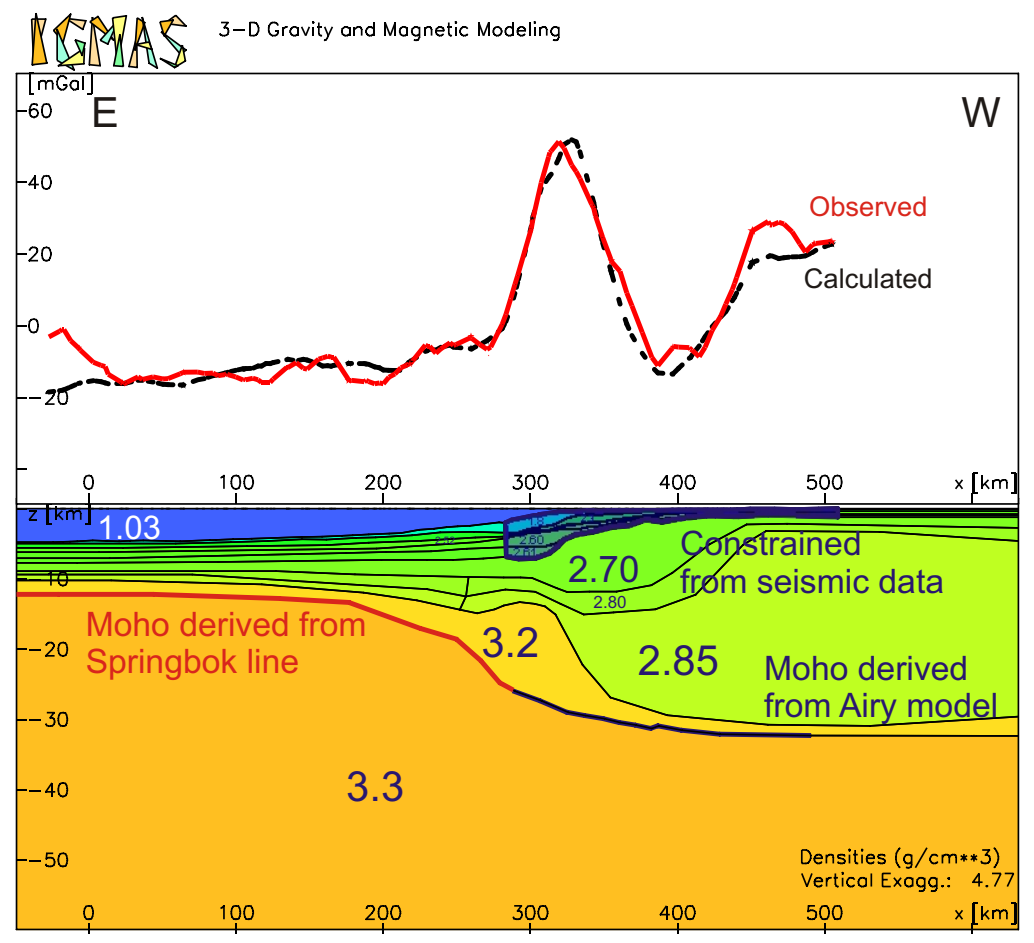

Figure 10: Final model, incorporating an inhomogeneous middle and lower crustal structure. 


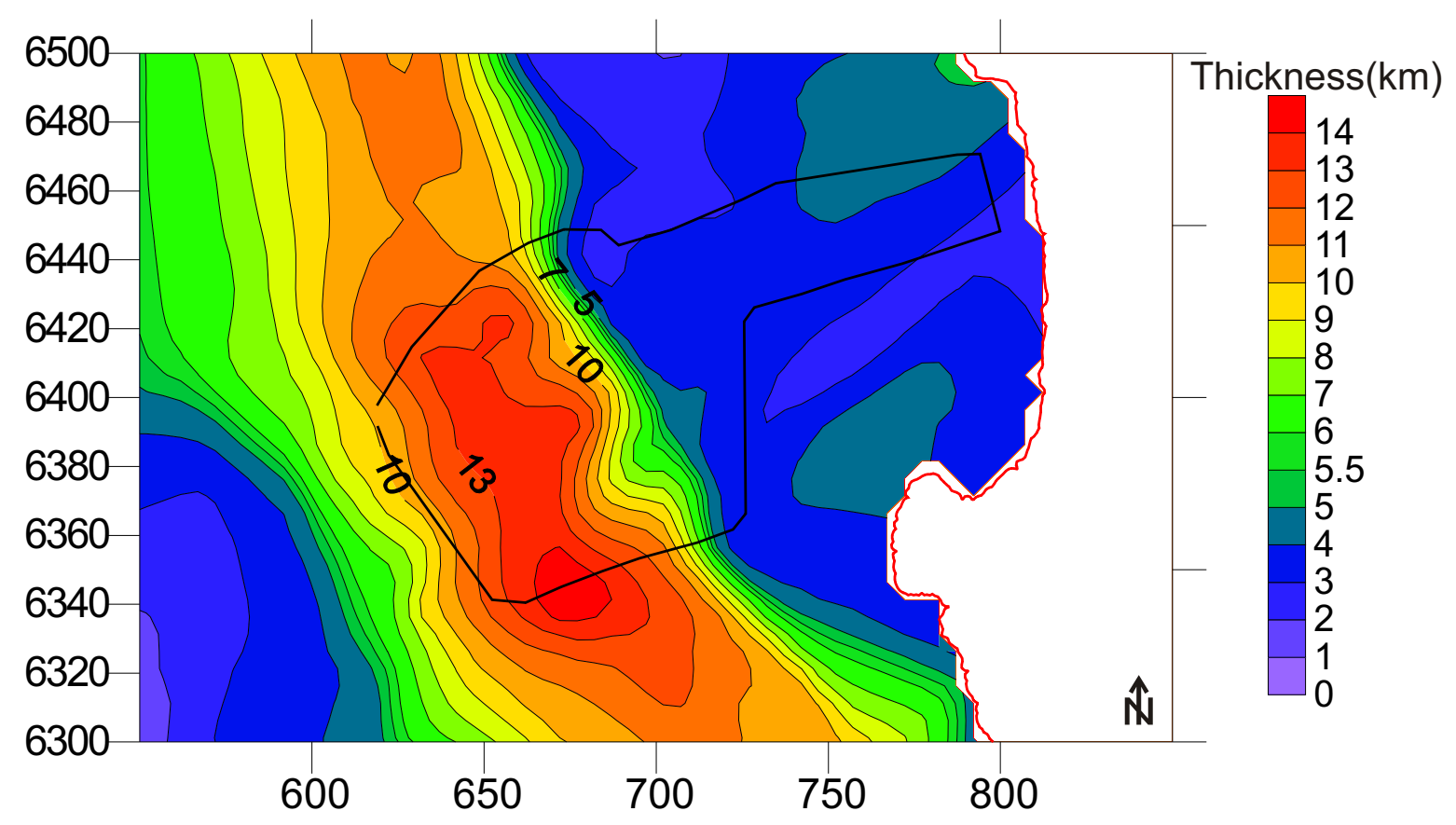

Figure 11: Thickness (in kilometres) of the high density body $\left(3.2 \mathrm{~g} / \mathrm{cm}^{3}\right)$ in the lower crust across the 3D geological model derived from gravity modelling. Map is in UTM coordinates (kilometres), Zone-33S. 


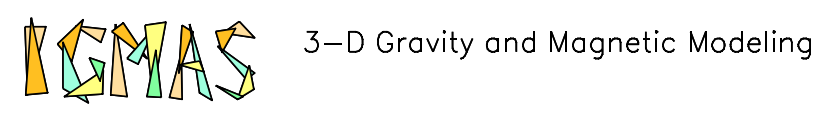

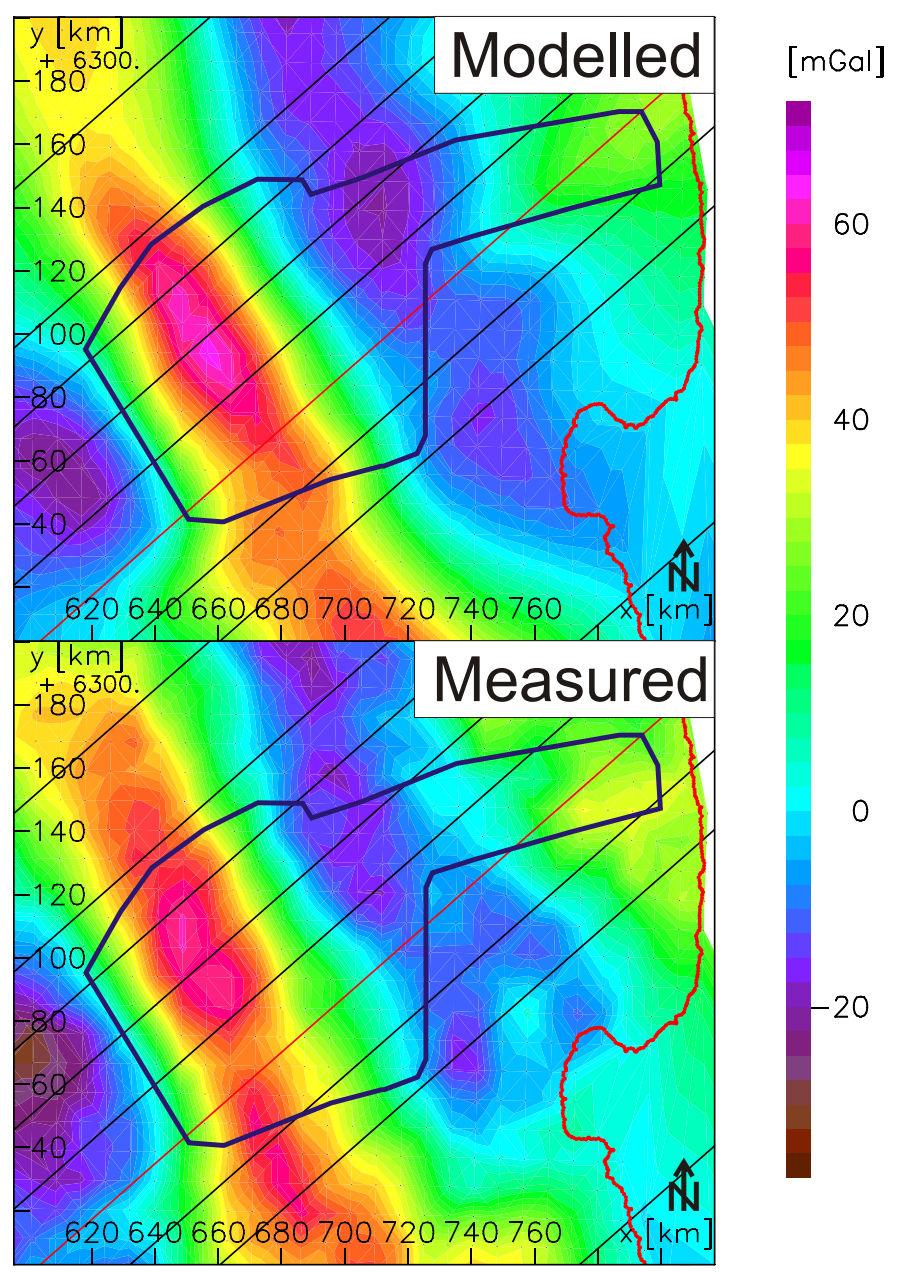

Figure 12: Comparison of measured versus calculated gravity field (interactive working planes are shown as diagonal lines). 